Received 10 April: accepted 5 May 1989

1. Marrack, P. \& Kappler, J. Adv. Immun. 38, 1-30 (1986

2. Brenner, M. B. et al. Nature 322, 145-149 (1986).

3. Groh, V. et al. J. exp. Med. 169, 1277-1294 (1989).

4. Chien, Y et al Nature 330, 722-727 (1987).

5. Hata, S. et al. Science 240, 1541-1544 (1988).

6. Modlin, R. L. \& Rea, T. H. Springer Semin. Immunopathol. 10, 359-374 (1988).

7. Mehra, V., Mason, L. H., Fields, J. P. \& Bloom, B. R. J. Immun. 123, 1813-1817 (1979).

8. Cooper. C. L. et al. J. exp. Med. (in the press).

9. Dugan, E., Modlin, R. L. \& Rea, T. H. Int. J. Leprosy 53, 404-409 (1985).

Brenner. M. B et al. I Immun 138, 1502-1509 (1987).

1. Band $\mathrm{H}$. et al. Science 238, 682-684 (1987).

Convit, J. Etiop. Med. 12, 187-195 (1974).

3. Borst, J. et al. Nature 325, 683-688 (1987)

4. Brenner, M. B. et al. Nature 325, 689-694 (1987).

5. Matis, L. A., Cron, R. \& Bluestone, J. A. Nature 330, 262-264 (1987)

6. Modlin, R. L. et at. Nature 329, 541-545 (1987)

7. Kindler, V., Sappino, A.-P., Grau, G. E., Pigue, P.-F. \& Vassalli, P. Cell 56, 731-740 (1989).

18. Bennett B. \& Bloom, B. R. Proc. natn. Acad Sci US. A. 59, 756-762 (1968).

9. Gendleman. H. E. et al. J. exp. Med. 167, 1428-1441 (1988)

White, J. et al. Cell 56, 27-35 (1989).

O'Brien, R. L. et al. Cell (in the press)

Janis, E. M.. Kaufman, S. H. E., Schwartz, R. H. \& Pardoll, D. M. Science (in the press)

Mcinnes, A. \& Rennick, D. M. L. exp. Med. 167, 598-611 (1988)

Ridley, D. S. \& Jopling, W. H. Int. J. Lepr. 34, 255-273 (1986).

Modlin, R. L. et al. J. Immun. 132, 3085-3090 (1984)

Modlin, R. L. et al. J. Immun 137, 2831-2834 (1986)

Modin R. et al Nature 322, 459-461 (1986)

Thote J. E et al Infect immunity 56, 1633-1640 (1988).

29. Booth, R. J., Harris, D. P., Love, J. M. \& Waston, J. D. J. Immun. 140, 597-601 (1988)

30. Hofman, F. M., Brock, M., Taylor, C. R. \& Lyons, B. J. Immun. 141, 1185-1190 (1988)

ACKNOWLEDGEMENTS. We thank Drs Craig Morita and Steve Porcelli for providing control $\gamma \delta$ T cell lines that were not antigen reactive and Drs $J$. van Embden and J. Watson for kindly providing recombinant mycobacterial antigens. Supported by the NHH, the UNDP/World Bank/WHO Specia Programme for Research and Training in Tropical Diseases (IMMLEP) and Vaccine Development (MMTUB) the National Hansen's Disease Center. Knights of Saint Lazarus of Jerusalem and Drown Foundation

\section{Identification of human CD4 residues affecting class II MHC versus HIV-1 gp120 binding}

\section{Linda K. Clayton* ${ }^{\dagger}$, Monica Sieh*, Donald A. Pious $\ddagger$ \& Ellis L. Reinherz*\&}

* Laboratory of Immunobiology, Dana-Farber Cancer Institute and Departments of $\uparrow$ Pathology and $\S$ Medicine, Harvard Medical School, 44 Binney Street, Boston, Massachusetts 02115, USA

$\ddagger$ Department of Pediatrics, University of Washington, Seattle, Washington 98195, USA

INTERACTIONS of CD4 with the class II major histocompatibility complex (MHC) are crucial during thymic ontogeny ${ }^{1}$ and subsequently for helper and cytotoxic functions of $\mathrm{CD4}^{+} \mathrm{CD8}^{-} \mathrm{T}$ lymphocytes $^{2-5}$. CD4 is the receptor for the T-lymphotropic human immunodeficiency virus and binds its envelope glycoprotein,

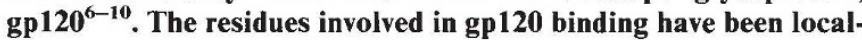
ized to a region within the immunoglobulin-like domain I of CD4, which corresponds to CDR2 of an immunoglobulin variable region $^{11-13}$, but the CD4 residues important in MHC class II interaction have not been characterized. Here, using a cell-binding assay dependent specifically on the CD4-MHC class II association, we analyse the effects of mutations in CD4 on class II versus gp120 binding. Mutations in CDR2 that destroy gp120 binding affect CD4-MHC class II binding similarly. In addition, binding of soluble gp120 to CD4-transfected cells abrogates their ability to interact with class II-bearing B lymphocytes. In contrast, other mutations within domains I or II that have no effect on gp120 binding eliminate or substantially decrease class II interaction. Thus, the CD4 binding site for class II MHC is more complex than the gp120 binding site, possibly reflecting a broader area of contact with the former ligand and a requirement for appropriate juxtaposition of the two N-terminal domains. The ability of gp120 to inhibit the binding of class II MHC to CD4 could be important in disrupting normal $\mathrm{T}$-cell physiology, acting both to inhibit immune responses and to prevent differentiation of $\mathrm{CD4}^{+} \mathrm{CD8}^{+}$ thymocytes into $\mathrm{CD4}^{+} \mathrm{CD8}^{-} \mathrm{T}$ lymphocytes.
To establish the structural basis of the CD4-class II MHC interaction, which could facilitate cell-cell contact ${ }^{2-5,14}$ and influence T-cell signal transduction ${ }^{15-17}$, we used a cell conjugate assay specific for binding of CD4 to class II MHC and investigated the effects of mutations in the first two immunoglobulinlike domains of the CD4 molecule on MHC binding. Wild-type or mutant CD4 molecules are expressed by transfection into COS- 1 cells and binding to MHC class II is measured by examining adhesion of class II MHC-expressing B cells to the COS-1 cells. As shown in Fig. $1 a$ (left panel), the Epstein-Barr virus transformed B-lymphoblastoid cell line, T51 (DR1, 3; DQ1, 2; DPX, 4$)^{18}$, binds readily to CD4-transfected COS-1 cells, but there is no T51 B-cell binding to COS-1 cells transfected with the CDM8 vector alone (Fig. 1 $a$, right panel).

The surface expression and structural integrity of each mutant CD4 was confirmed by fluorescence-activated cell sorter (FACS) analysis using the monoclonal antibody OKT4. Each mutant was also tested for gp120 binding. Examples are shown in Fig. $1 b$, and results for all mutants are presented in Table 1 . Wild-type CD4- and mutant M1B-transfected COS-1 cells bind equivalent amounts of OKT4 and gp120 (Fig. 1b); M3, although reactive with OKT4, fails to bind gp $120^{13}$. Although M3 reactivity with monoclonal antibodies OKT4 and 19Thy5D7 is slightly lower than that of CD4, we found identical binding activity with the anti-CD4 monoclonal antibody MT321, which binds an epitope in domain IV (ref. 8; data not shown). These results show that equivalent amounts of surface CD4 are obtained when COS-1 cells are transfected with $\mathrm{M} 3$ and CD4 complementary DNAs, indicating that the M3 mutation may directly or indirectly perturb the epitopes seen by OKT4 and 19Thy5D7.

To test the specificity of our assay further, we investigated the effects of monoclonal antibodies directed against the individual components of the system. As shown in Fig. $2 a$, binding of the T51 B cells is markedly inhibited by monoclonal antibodies to CD4 (OKT4) and class II MHC (9/49), but is unaffected by monoclonal antibodies directed against CD8 (7Pt3F9) or class I MHC (W6/32). We obtained identical results for the genotypically unrelated B cell line JY (data not shown). In addition, the MHC class II antigen loss B-cell mutant line, 6.1.6, which fails to express any class II MHC alleles from either haplotype, does not bind to CD4-transfected COS-1 cells (Fig. $2 b)$. In contrast, the mutant cell lines that express at least one complete haplotype, 9.28.6 (DR1, - ; DQ1, - ; DPX, - ) and 8.1.6 (DR3,-; DQ2,-; DP4, X), bind, but at reduced levels. This result shows that different polymorphic alleles of class II MHC can bind to CD4. It is notable that the loss variants 4.36 .4 and 11.11.4, which express only DQ1, DPX and DQ1 respectively, do not bind to CD4-expressing COS-1 cells. Whether the lack of binding of DR-negative B-cell variants is due to the low level of expression of DP and/or DQ in these cells as compared with DR (our unpublished observation), or is indicative of a lower affinity of CD4 for DP or DQ relative to DR cannot be determined at present. It has been shown, however, that these $D P$ and $D Q$ alleles are functional as restrictional elements in T-cell responses ${ }^{18}$. Furthermore, in the murine system, liposomes containing either murine I-A or I-E molecules bind CD4-expressing cells ${ }^{19}$

The murine CD4 sequence is $50 \%$ identical with its human homologue $\mathrm{e}^{20}$ and binds poorly to T51 B cells, the extent being similar to the binding shown in Fig. $1 a$ (middle panel) for mutant M11 (see below). Given the obvious difference in binding of human class II-expressing B cells to human versus mouse CD4-transfected COS-1 cells, we used oligonucleotide-directed mutagenesis to create 17 individual CD4 mutants incorporating all non-conservative (polarity and/or charge change) murine for human substitutions between amino-acid residues 17 and 167. Each human CD4 mutant contains between one and four murine amino-acid substitutions. The positions of these are shown in Fig. 3, with specific residue changes listed in Table 1. Each mutant was transfected into COS-1 cells, assayed for 
FIG. 1 Expression of CD4 and cellular adhesion with MHC class II-expressing B cells in transfected COS-1 cells. a, Binding of T51 B cells to COS-1 cells transfected with CD4 (left panel), CD4 mutant M11 (middle panel) or CDM8 vector only (right panel). $b$, FACS analysis of anti-CD4 monoclonal antibody OKT4 and gp 120 binding to COS-1 cells transfected with wild-type $\mathrm{CD} 4, \mathrm{M} 1 \mathrm{~B}$ and $\mathrm{M} 3$ mutants.

METHODS. Plasmid pSP65-T4 (gift from Dan Littman) was digested with $\mathrm{BamHI}$ and $\mathrm{XhOl}$ to release the CD4 insert. The insert was blunted with the Klenow fragment of DNA polymerase I, ligated to $X b a$ linkers (New England Biolabs) and subcloned into the Xba site of the vector CDM8 (ref. 33). COS-1 cells were transfected with CDM8 constructs as described $^{13}$, but with the following modifications: $0.3 \times 10^{6}$ cells were plated into each well of Falcon 6-well dishes and $6 \mu \mathrm{g}$ plasmid DNA ( $\mathrm{CsCl}$-banded twice) in $0.35 \mathrm{ml}$ RPMl plus $0.35 \mathrm{ml} \mathrm{RPMI-} 800 \mu \mathrm{g} \mathrm{ml}^{-1}$ DEAE dextran was used for transfection. Binding of B cells to transfected COS-1 cells was assayed two days after transfection as described ${ }^{14}$, with the following modifications: transfected COS-1 cells were washed once with RPMl and $1-2 \times 10^{7} \mathrm{~B}$ cells were added to each $35 \mathrm{~mm}$ well in $0.8 \mathrm{ml} \mathrm{RPMI}, 2 \%$ fetal calf serum, $1 \%$ glutamine, $1 \%$ penicillin-streptomycin, $10 \mathrm{\mu g} \mathrm{ml}^{-1}$ gentamicin (final medium). The mixed cells were incubated for one hour at $37^{\circ} \mathrm{C}$, the $\mathrm{B}$ cells aspirated and the well was washed $3-5$ times by dropping $2 \mathrm{ml}$ final medium into the well. Binding was scored as,$++/-$ or - after viewing each well by phase contrast microscopy at a magnification of $100 \times$. A plus value represents binding equivalent to that obtained with COS-1 cells transfected with wild-type CD4 DNA. A minus value is indistinguishable from transfection results obtained with CDM8 alone. $A+/-$ value represents substantially reduced.

but still detectable, binding (10-20\% wild-type binding). A negative control of CDM8-transfected COS-1 cells and a positive control of wild-type CD4transfected COS-1 cells were included in every assay. We consistently obtained wild-type CD4 expression in $50-60 \%$ of $\operatorname{COS}-1$ cells at equivalent levels of mean channel fluorescence in $>36$ separate transfections. Every $B$ cell-binding assay for wild-type and mutant $\mathrm{CD} 4 \mathrm{~s}$ was accompanied by FACS analysis and always gave reproducible results ( $n \geqslant 3$ for each mutant). For FACS analysis, COS-1 cells transfected with the mutant indicated were scraped from the well, stained with monoclonal antibodies OKT4, 19Thy5D7 or MT321 (gift from P. Rieber) (1:500 and 1:100 dilution of ascites for

surface expression of CD4 and for gp120 binding by FACS analysis, and tested for adhesion of T51 B cells. Results are given in Table 1. Seven mutants dramatically reduced or eliminated class II MHC binding. These include three mutations in the CDR1 homologous region of domain I (ref. 13), mutants M1.1, M1.2 and M1B; one mutation in the CDR2 equivalent region $^{13}$, mutant $\mathrm{M} 3$; one mutation unrelated to any CDR, M5; one mutation immediately distal to the CDR3 homologue, M8; and one mutation in domain II, M11. An example of a mutation that reduces B-cell binding is shown in Fig. $1 a$ (middle panel)

FIG. 2 Specificity of binding of CD4 transfected COS- 1 cells to MHC class II-expressing B cells. $a$, Inhibition of T51 B-cell binding by monoclonal antibodies and gp120 b. Binding of EBV-transformed MHC class II antigen loss mutant B-cell lines to CD4-transfected COS-1 cells.

METHODS. For calculation of the number of $B$ cells bound, $10^{8} B$ cells were labelled for $2 \mathrm{~h}$ at $37{ }^{\circ} \mathrm{C}$ in 0.5 to $1.0 \mathrm{mCi}$ of ${ }^{51} \mathrm{Cr}$, washed four times and then used for binding, as described in the legend to Fig. 1. An aliquot of labelled cells was used to determine the specific activity which ranged from 0.01 to 0.1 c.p.m. per B cell. After washing the unbound B cells from individual wells, $1 \mathrm{ml}$ PBS containing $1 \%$ Triton was added to each well. Cells were incubated $15 \mathrm{~min}$ at $37^{\circ} \mathrm{C}$, lysates spun to remove cell debris and $100 \mu \mathrm{l}$ supernatant counted to determine the number of $B$ cells bound to transfected COS-1 cells. Each B-cell line was assayed for binding in duplicate wells of CD4-transfected COS-1 celis in two independent experiments. Counts bound to CDM8-transfected well were subtracted from counts bound to CD4transfected wells. For T51, c.p.m. bound to CD4-transfected COS-1 cells were always 2-3 times the c.p.m. bound to CDM8-transfected COS-1 cells. For antibody-inhibition studies, monoclonal antibodies were added at a $1: 100$ dilution to $B$ cells and transfected COS-1 cells, the cells incubated $30-60 \mathrm{~min}$ at $37^{\circ} \mathrm{C}$, then mixed and assayed as described in the legend to Fig. 1. Monoclonal antibodies used were: anti-CD4, OKT4; anti-CD8, 7Pt3F9; anti-class I, W6/32; anti-class II, 9/49. Recombinant gp120 from the H3DCG isolate of HIV-1 (Genentech) and ovalbumin (Sigma) were added to a final


OKT4 and 19Thy5D7, respectively, and purified MT321 at $20 \mu \mathrm{g} \mathrm{ml}^{-1}$ ) and analysed after staining with a 1:40 dilution of FITC-conjugated goat antimouse immunoglobulin (Meloy) on an Epics V cell sorter (Coulter). Propidium iodide was included to gate out dead cells. The anti-CD2 monoclonal antibody 3T4-8B5 was used as a negative control. For gp120 binding, cells were scraped from the well, incubated with $1 \mu \mathrm{g} g \mathrm{~g} 120$ in $0.1 \mathrm{mi}$ for $30 \mathrm{~min}$ on ice, stained with $200 \mathrm{ng}$ monoclonal anti-gp120 antibody (Dupont) and FITC-conjugated second antibody and analysed by FACS as above. As a negative control for anti-gp120 antibody staining, no gp120 was added.

for the M11 mutant. M1.1, M1.2 and M5 also gave a reduced B-cell binding phenotype. The mutants M1B, M3 and M8 were indistinguishable from vector-only transfectants (Fig. 1a, right panel). The other mutations were without effect.

In contrast to the large number of mutations that affect class II MHC binding, only M3 abrogated gp120 binding (Fig. $1 b$ and Table 1). Note that mutants M6, M9 and M14 could not be evaluated as their alterations grossly affect the structure of the external CD4 domains, so that reactivity with all our antiCD4 monoclonal antibodies is reduced or, in the case of M14,
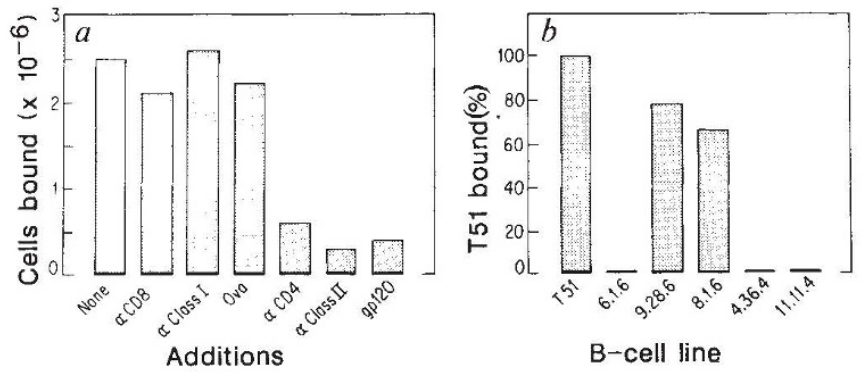

concentration of $20 \mu \mathrm{g} \mathrm{ml}^{-1}$ to the B cells and transfected COS-1 cells, the cells incubated $30-60 \mathrm{~min}$ at $37^{\circ} \mathrm{C}$, mixed and assayed. MHC-surface expression of the class II antigen-loss mutant EBV-transformed B cell lines was confirmed by FACS using the following monoclonal antibodies; 9/49 binds to a common determinant on DR, DP and DQ (ref. 34), L243 binds DR (ref. 35), and B7/21 (gift from I. Trowbridge) binds DP, Mutant B-cell haplotypes: T51 (parental, DR1, 3; DQ1, 2; DPX, 4) (ref 36); 6.1.6 (DR-,-; DQ-,-; DP-,-) (ref. 37); 9.28.6 (DR1,-; DQ1,-; DPX,-) (ref. 36); 8.1.6 (DR3,-; DQ2,-; DP4, X) (ref. 36); 4.36 .4 (DR,--; DQ1,-; DPX,-) (ref. 38); 11.11.4 (DR-,-; DQ1,-; DP-,-) (ref. 38). In $b$, specific binding was 8,842 c.p.m. 
eliminated. All the other 14 mutants, when transfected into COS-1 cells, yielded a copy number of variant CD4 molecules equivalent to the copy number of wild-type CD4, as assessed by quantitative FACS analysis with anti-CD4 monoclonal antibodies OKT4, 19Thy5D7 and/or MT321.

Using the immunoglobulin $\mathrm{V}_{\kappa}$ Bence-Jones homodimer, REI

TABLE 1 Analysis of CD4 mutants for expression, gp120 binding and MHC class II binding

\begin{tabular}{|c|c|c|c|c|}
\hline Mutant & $\begin{array}{l}\text { Amino-acid } \\
\text { change* }^{*}\end{array}$ & $\begin{array}{l}\text { Antibody } \\
\text { reactivity }\end{array}$ & $\begin{array}{l}\text { gp120 } \\
\text { binding }\end{array}$ & $\begin{array}{c}\text { Class II } \\
\text { MHC } \\
\text { binding }\end{array}$ \\
\hline M1.1 & $\begin{array}{l}17, T \text { to } E \\
18, A \text { to } S\end{array}$ & + & + & $+1-$ \\
\hline M1.2 & $\begin{array}{l}23, \mathrm{~S} \text { to } \mathrm{I} \\
24,1 \text { to } \mathrm{T} \\
25, \mathrm{Q} \text { to } \mathrm{V}\end{array}$ & + & + & $+1-$ \\
\hline M1B & $\begin{array}{l}27, \mathrm{H} \text { to } \mathrm{T} \\
30, \mathrm{~N} \text { to } \mathrm{F} \\
32, \mathrm{~N} \text { to } \mathrm{D} \\
34, \mathrm{I} \text { to } \mathrm{R}\end{array}$ & + & + & - \\
\hline M2 & $40, \mathrm{Q}$ to $\mathrm{H}$ & + & + & + \\
\hline M3 & $\begin{array}{l}48, P \text { to } G \\
50, K \text { to } P \\
51, L \text { to } S\end{array}$ & + & - & - \\
\hline M4 & $64, \mathrm{Q}$ to $\mathrm{K}$ & + & + & + \\
\hline M5 & $\begin{array}{l}72, \mathrm{~K} \text { to } \mathrm{N} \\
73, \mathrm{~N} \text { to } \mathrm{K}\end{array}$ & + & + & $+1-$ \\
\hline M6 & $80, \mathrm{D}$ to $\mathrm{Q}$ & $\downarrow$ & NE & NE \\
\hline M7 & $\begin{array}{l}88, \mathrm{D} \text { to } \mathrm{N} \\
89, \mathrm{Q} \text { to } \mathrm{R} \\
94, \mathrm{Q} \text { to } \mathrm{E}\end{array}$ & + & + & + \\
\hline M8 & $\begin{array}{l}99, \mathrm{G} \text { to } \mathrm{K} \\
104, \mathrm{~S} \text { to } \mathrm{P} \\
107, \mathrm{H} \text { to } \mathrm{S}\end{array}$ & + & + & - \\
\hline M9 & $\begin{array}{l}121, P \text { to } S \\
122, P \text { to } K \\
123, G \text { to } V\end{array}$ & $\downarrow$ & NE & $\mathrm{NE}$ \\
\hline M10 & $\begin{array}{l}127, \mathrm{~S} \text { to } \mathrm{L} \\
128, \mathrm{~V} \text { to } \mathrm{T} \\
129, \mathrm{Q} \text { to } \mathrm{E}\end{array}$ & + & + & + \\
\hline M11 & $\begin{array}{l}132, \mathrm{~S} \text { to } \mathrm{H} \\
133, \mathrm{P} \text { to } \mathrm{K} \\
137, \mathrm{~N} \text { to } \mathrm{V}\end{array}$ & + & + & $+1-$ \\
\hline M12 & $143, \mathrm{~T}$ to $\mathrm{V}$ & + & + & + \\
\hline M13 & $150, E$ to $R$ & + & + & + \\
\hline M14 & $\begin{array}{l}155, G \text { to } D \\
156, T \text { to } F \\
158, T \text { to } N\end{array}$ & - & $\mathrm{NE}$ & NE \\
\hline M15 & $\begin{array}{l}162, \mathrm{~L} \text { to } \mathrm{T} \\
163, \mathrm{Q} \text { to } \mathrm{L} \\
164, \mathrm{~N} \text { to } \mathrm{D}\end{array}$ & + & + & + \\
\hline
\end{tabular}

The monoclonal antibody reactivity and gp120 binding were determined by FACS analysis as described in the legend to Fig. 1. Symbols: + , antibody reactivity equivalent to that obtained with wild-type CD4-transfected COS-1 celis; $\downarrow$, levels of expression $\sim 2$ logs lower; - , no detectable expression. Results are shown for monoclonal antibody OKT4, except in the case of M3 and M8, for which monoclonal antibody MT321 was used. Class II MHC binding was quantitated as described in the legend to Fig. 1. +, Binding of T51 B cells similar to that depicted in Fig. 1 a (left panel) and $\geqslant 90 \%$ of that obtained with wild-type CD4, as depicted by the quantitative method given in Fig. 2 legend; $+/-$, binding of T51 B cells similar to that depicted in Fig. 1 a (middle panel) and $10-20 \%$ of that obtained with wild-type CD4;- , no detectable binding, as depicted in Fig. 1 a (right panel) and $<10 \%$ of that obtained with wild-type CD4. Note that no mutants gave class II MHC binding between $20 \%$ and $90 \%$ of the wild-type CD4. NE, not evaluated because of low expression. * Position, nature of substitution (one-letter code). (ref. 21), as a model for the CD4 N-terminal domain, the positions of mutants in domain I of CD4 that affect gp120 binding could be assigned to the CDR2 segment ${ }^{13}$. But our analysis of class II MHC binding indicates that a single localized segment is not involved. Rather, residues spread through a substantial portion of the molecule are implicated in CD4-class II interactions. These include amino acids ${ }^{13}$ in the CDR1- and 2-like regions and a segment distal to CDR3 modelled using a published alignment of CD4 and $\mathrm{V}_{\kappa}$ proteins ${ }^{10}$. Although some or all of these residues may be contact sites for MHC class II, we cannot exclude the possibility that alteration of residues in these regions affects class II MHC binding to CD4 elsewhere in the molecule. Also, the involvement of regions outside the predicted CDR-like loops such as M5, which is probably located at the opposite pole of the domain from the CDRs ${ }^{13,22}$, suggests that interaction of CD4 with class II MHC may not be exclusively immunoglobulin-like with respect to binding of ligand by CDR loops. Furthermore, CD4 monomers may interact with one another to create a functional binding site.

Because the CD4 amino-acid residues affecting class II MHC binding are scattered throughout domain I and include at least a stretch in domain II, we speculate that the interactive surface interface between CD4 and class II MHC is much broader than the putative gp120-binding site in CD4. Binding of CD4 with gp120 was only abrogated by the M3 mutation. If both domains I and II are critical for class II MHC binding, then mutations affecting the interaction of these domains with each other might also abolish binding, which could be one effect of mutations outside the regions equivalent to the CDRs. Evidence for the proximity of domains I and II is provided by the fact that antibodies which bind to separate epitopes on these domains cross-block one another's binding to CD4 (ref. 11). It is also possible that there are several discontiguous binding regions for class II MHC.

As M3 abrogated binding of both class II MHC and gp120, we examined the effect of gp120 itself on class II MHC interaction with CD4. Preincubation of $\mathrm{B}$ cells with a concentration of gp120 that saturates CD4 binding sites $\left(20 \mu \mathrm{g} \mathrm{ml}^{-1}\right)$ inhibits CD4-class II MHC binding (Fig. $2 a$ ). This inhibition of $\mathrm{B}$ cell binding to CD4-expressing COS-1 cells is not a result of down-
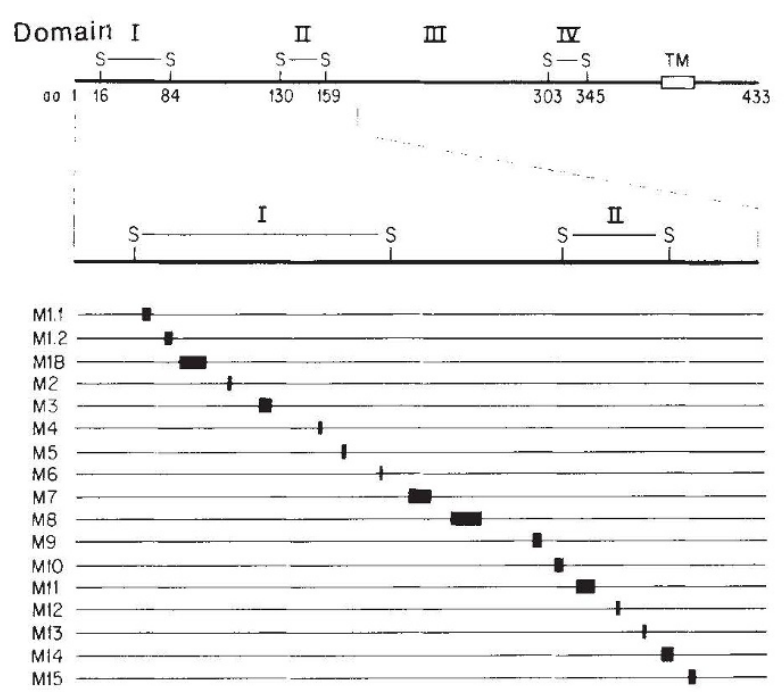

FIG. 3 Positions of mutations in CD4. A schematic diagram of the CD4 protein showing the four immunoglobulin like domains, three disulphide bonds, transmembrane region and cytoplasmic tail. Numbering of amino acids is according to ref. 23. The expanded portion shows the positions of substitutions in 17 different mutants. Mutations were created using the thionucleotide method of oligonucleotide site-directed mutagenesis as described $^{13}$, except that the template for mutagenesis was the full-length CD4 cDNA in M13 phage. The structure of all mutants was confirmed by DNA sequence analysis of the CDM8-CD4 mutant construct using the double stranded DNA as a template. 
modulation of CD4 on the transfected cells as their reactivity with OKT4 is unchanged (data not shown). Unlike gp120, soluble $\mathrm{CD} 4\left(\mathrm{~T} 4_{\text {ex } 1}\right)$ (ref. 23), even at a concentration of $1 \mathrm{mg} \mathrm{ml}^{-1}$, has no effect on binding of B cells, leaving unaffected conjugates such as those seen in Fig. $1 a$ (left panel). This is consistent with the affinity of the monomeric CD4-MHC interaction being much lower (by about $\geqslant 4$ orders of magnitude) than that of CD4 for gp120 (ref. 24), as well as with the lack of inhibition by soluble CD4 of class II-restricted T-cell responses ${ }^{23}$. Given the low affinity of monomeric CD4 for class II MHC, the greatly up-regulated expression of CD4 copy number on activated T-lymphocyte clones ${ }^{25}$ probably enhances interactions of $\mathrm{CD}^{+}$cells with Ia-expressing cells through an increase in multipoint attachment.

The inhibition of the CD4-class II interaction by gp120 may be significant in T-cell function in HIV-infected individuals in whom gp120 is shed systemically ${ }^{26} . \mathrm{CD}^{+} \mathrm{T}$ cells can be depleted by direct lytic infection ${ }^{27}$, viral cytopathic effects such as syncitia formation $^{28,29}$, or by a gp 120 -specific cytolytic mechanism ${ }^{30}$, but our results have direct implications for the functional activity of the residual normal $\mathrm{CD}^{+}{ }^{+} \mathrm{T}$ cells. Specifically, gp120 inhibition of CD4 interaction with class II MHC on antigen-presenting cells could inhibit helper T-cell responses which are virtually all class II-restricted, thereby paralysing the normal residual $\mathrm{CD}^{+} \mathrm{T}$ lymphocytes. T-cell responses are inhibited by gp 120 in vitro ${ }^{31,32}$ and our findings provide direct evidence for inhibition of MHC class II-CD4 binding by soluble gp120, which is probably the basis for the observed immunosuppression. Furthermore, it has recently been shown that $\mathrm{CD} 4^{+} \mathrm{CD} 8^{+}$precursor $\mathrm{T}$ lymphocytes develop into $\mathrm{CD} 4^{+} \mathrm{CD} 8^{-} \mathrm{T}$ lymphocytes as a consequence of interaction between CD4 and class II MHC during thymic development ${ }^{1}$, so disruption of this interaction by gp120 might block subsequent production of $\mathrm{CD}^{+} \mathrm{T}$ lymphocytes.

\footnotetext{
Received 6 March; accepted 10 May 1989.
}

1. Kruisbeek, A. M. et al. 1. exp. Med. 161, 1029-1047 (1985).

2. Krensky, A. M., Reiss, C. S., Mier, J. W., Strominger, J. L. \& Burakoff, S. J. Proc. natn. Acad. Sci. U.S.A. 79, 2365-2369 (1982)

3. Meuer, S. C.. Schlossman, S. F. \& Reinherz, E. L. Proc. natn. Acad. Sci. U.S. A. 79, 4395-4399(1982)

4. Biddison, W., Rao, P., Talle, M. A., Goldstein, G. \& Shaw, S. J. J. exp. Med. 156, 1065-1076 (1982)

5. Marrack, P. et al. J. exp. Med. 158, 1077-1091 (1983)

6. Klatzmann, D. et al. Science 225, 59-63 (1984).

7. Daigieish, A. G. et al. Nature 312, 763-766 (1984)

B. Sattentau, Q., Dalgleish, A., Weiss, R. \& Beverley, P. C. L. Science 234, 1120-1123 (1986).

9. McDougal, J. S. et al. Science 231, 382-385 (1986).

10. Maddon, P. J. et al. Cell 47, 333-348 (1986).

11. Peterson, A. \& Seed, B. Cell 54, 65-72 (1988).

12. Landau, N. R., Warton, M. \& Littman, D. R. Nature 334, 159-162 (1988).

13. Clayton, L. K. et at. Nature 335, 363-366 (1988).

14. Doyle, C. \& Strominger, J. L. Nature 330, 256-259 (1987),

15. Eichmann, K., Jonsson, J. I., Falk, I. \& Emmrich, F. Eur. J. Immun. 17, 643-650 (1987).

16. Rudd, C. E., Trevillyan, J. M., Dasgupta, J. D., Wong, L. L. \& Schlossman, S. F. Proc. natn. Acad Sci. U.S.A. 85, 5190-5194 (1988).

17. Veillette, A., Bookman, M. A. Horak, E. M. \& Bolen, J. B. Cell 55, 301-308 (1988)

18. Mellins, E., Woelfel, M. \& Pious, D. Hum. Immun. 18, 211-223 (1987).

19. Gay, D., Buus, S., Pasternak, J., Kappler, J. \& Marrack, P. Proc. natn. Acad. Sci. U.S.A. 85, 5629-5633 (1988)

20. Maddon, P. J. et al. Proc. natn. Acad. Sci. U.S.A. 84, 9155-9159 (1987).

21. Epp, O., Lattman, E. E., Schiffer, M., Huber, R. \& Palm, W. Biochemistry 14, 4943-4952 (1975)

22. Richardson, N. E. et al. Proc. natn. Acad. Sci. U.S.A. 85, 6102-6106 (1988).

23. Hussey, R. E. et al. Nature 331, 78-81 (1988)

24. Lasky, $L$ et al. Cell $50,975-985$ (1987).

25. Meuer, S. C. et al. Nature $303,808-810$ (1983).

26. Schneider, I., Kaaden, O., Copeland, J. D., Oroslan, S. \& Hunsmann, G. J. gen. Virol. 67, 2533-2539 (1986)

27. Samasundaran, M. \& Robinson, H. L. J. Virol, 61, 3114-3119 (1987)

28. Sodroski, J., Goh, W. C., Rosen, C., Campbell, K. \& Haseitine, W. A. Nature 322, 470-474 (1986)

29. Lifson, J. et al. Nature 323, 725-728 (1986).

30. Siliciano, R. F. et al. Cell 54, 561-575 (1988).

31. Diamond. D. C. et al. J. Immun. 141, 3715-3717 (1988)

32. Weinhold, K. J. et al. J. Immun. (in the press).

33. Seed, B. \& Aruffo, A. Proc. natn. Acad. Sci. U.S.A. 84, 3365-3369 (1987).

34. Pesando, J. M. \& Graf, L. J. Immun. 136, 4311-4318 (1986)

35. Lampson, L. A. \& Levy, R. L. Immun. 125, 293-299 (1980)

36. Levine, F. et al. Proc. natn. Acad. Sci. U.S.A. 82, 3741-3745 (1985).

37. Levine, F., Erlich, H., Mach. B. \& Pious, D. J. Immun. 134, 637-640 (1985).

38. Pious, D., Dickson, L., Levine, F., Cotner, T. \& Johnson, R. J. J. exp. Med. 162, 1193-1207 (1985).

ACKNOWLEDGEMENTS. We thank Professor Stephen C. Harrison for advice and assistance with computer modelling. Drs George Tarr, Shigeo Koyasu and Frederick Cohen for critical reading of this manuscript and Dr Gordon Freeman for advice on COS-1 cell transfections. This work was supported in part by the NIH.
The CD2 antigen associates with the T-cell antigen receptor CD3 antigen complex on the surface of human T lymphocytes

\author{
Marion H. Brown*, Doreen A. Cantrell†, \\ Göran Brattsand $\ddagger$, Michael J. Crumpton* \\ \& Martin Gullberg $\div$
}

* Cell Surface Biochemistry, † Lymphocyte Activation Laboratories, Imperial Cancer Research Fund, Lincoln's Inns Fields, London WC2A 3PX, UK

末 Unit for Applied Cell \& Molecular Biology, University of Umeå, S-90187 Umeå, Sweden

T LYMPHOCYTES can be activated by various stimuli directed either against the $\mathrm{T}$-cell antigen receptor-CD3 antigen complex (Ti-CD3) or the CD2 molecule; see ref. 1 for a review. Activation signals generated by antigen binding to the antigen-specific $\alpha / \beta$ heterodimer (Ti) are thought to be transduced via the invariant CD3 $\gamma, \varepsilon$ and $\delta$ chains, and the associated $\zeta$ and $\eta$ subunits $^{2,3}$. The physiological role of the interaction of $\mathrm{CD} 2$ with its homologous cell-surface associated ligand LFA-3,5 remains to be fully elucidated. It has been suggested that $\mathrm{CD2}$ regulates an antigen-independent pathway of activation ${ }^{6}$ or that signals delivered via $\mathrm{CD} 2$ are an integral part of the antigen-specific pathway $^{7-10}$. Several recent studies have indicated a requirement for the Ti-CD3 complex in CD2 signalling. Thus, mutant T-cell lines expressing $\mathrm{CD2}$, but not $\mathrm{Ti}-\mathrm{CD} 3$, on the cell surface cannot be activated via the CD2 molecules, ${ }^{9}$. Functional interaction between the Ti-CD3 complex and the CD2 antigen suggests that these T-lymphocyte cell-surface structures are physically associated. Here we use a digitonin-based solubilization procedure to explore this possibility and show that $40 \%$ of the cell-surface CD2 molecules can be specifically co-precipitated in association with the Ti-CD3 complex.

Immunoprecipitates of the Ti-CD3 complex were prepared from normal $\mathrm{T}$ lymphoblasts labelled at the surface by lactoperoxidase-catalysed iodination and lysed in digitonin to preserve noncovalent associations. SDS-PAGE analysis under nonreducing conditions of an immunoprecipitate, which had been prepared using UCHTI, a monoclonal antibody against CD3, revealed the characteristic $\gamma$-, $\delta$ - and $\varepsilon$-chains of CD3, plus a band migrating with a relative molecular mass $M_{\mathrm{r}}$ of 90,000 (90K) comprising the disulphide-linked $\alpha$ - and $\beta$ - chains of Ti (Fig. 1, lane 1). In addition, a diffuse band at $50-55 \mathrm{~K}$ was clearly visible which showed remarkable similarity in mobility and appearance to the authentic CD2 immunoprecipitate shown in lane 2. Under reducing conditions, the $\alpha$-chain of Ti has an $M_{\mathrm{r}}$ of $50-55 \mathrm{~K}$, making it difficult to identify any other molecule of similar mobility in the CD3 immunoprecipitate (lane 4). The appearance of CD2 in the CD3 immunoprecipitate represents genuine co-precipitation and was not due to cross-reactivity of UCHTI with CD2. This was demonstrated by preparing immunoprecipitates using UCHTI from digitonin lysates of insect Sf9 cells expressing high levels of CD2 after infection with a recombinant baculovirus. Under these circumstances, no specific precipitation of CD2 by UCHTI was detected (data not shown).

To provide evidence that the $50-55 \mathrm{~K}$ band which coprecipitated with the Ti-CD3 complex was the CD2 antigen, we performed a depletion experiment. A digitonin lysate, depleted of CD2 antigen by pre-clearing with a monoclonal antibody against CD2 (lane 8), was reprecipitated with a monoclonal antibody against $\mathrm{CD} 3$. Analysis of this $\mathrm{CD} 3$ precipitate under nonreducing conditions (lane 10 ) revealed no band at $50-55 \mathrm{~K}$, suggesting that the band observed in this region in lane 1 did 